\title{
An exploratory study of possible food waste risks in supermarket fruit and vegetable sections
}

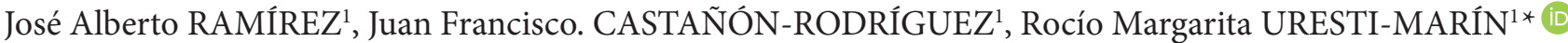

\begin{abstract}
Food waste is an emerging issue in terms of food policy; the most common cause of fruit and vegetable waste at a retailer, in addition to excess stock and consumer behaviour, is the lack of employees certified in food handling. Fruits and vegetables require specific handling and storing to avoid waste. The objective of this work was to survey the employees of fruit and vegetable sections in supermarkets to understand their experience and the reasons they believe products are wasted. The results show that most employees have secondary educations; the average age of these employees is 33 with at least one year working for the company; and no significant correlation was found between age and seniority in the company. In comparison to international supermarkets, national supermarkets train their employees less. Employees perceived the best-selling fruits to be bananas, apples, papayas, melons and pineapples and the vegetables to be tomatoes, onions, green peppers (serrano), and potatoes, which are essential in Mexican cuisine, and their perceptions of best-selling produce were related to waste, probably due to the widespread availability of these types of produce. One of the strategies to avoid wasting fruits and vegetables in good condition is donating them to food banks.
\end{abstract}

Keywords: food waste; supermarkets; fruits and vegetables; food handling.

Practical Application: The practical application of the knowledge of this article is that the need for trained personnel in the handling of fruits and vegetables in stores was identified, since they are perishable food products.

\section{Introduction}

Recently, food waste has received increasing interest from policymakers in various fields worldwide. There are enough studies that note that a reduction in FLW can positively influence food security and mitigation of climate change (Wunderlich \& Martinez, 2018), and thus, studies carried out in countries with advanced economies have focused on quantifying and characterizing FLW (Broekmeulen \& Van Donselaar, 2019), and related proposed quantification methodologies (Barco et al., 2019; Corrado et al., 2019), although this is an expensive process that countries with middle- and low-income economies cannot afford. Additionally, it is estimated that approximately one-third of the food for human consumption is lost or wasted from the farm to the table (Food and Agriculture Organization of the United Nations, 2011a). Food waste (FW) refers to the decision to pull foods that are safe for human consumption and that retain their nutritive value; this action is mainly associated with the behaviour of wholesalers and retailers, the retail sale of prepared food and the actions taken by the final consumer at home (Parfitt et al., 2010). FW is separated into five generation sources: agricultural production, postharvest handling, storage, processing, distribution, and consumption (Gustavsson et al., 2011). Figure 1 shows the origin of FLW, according to the Food and Agriculture Organization of the United Nations (2014).
The world demand for food will increase by $70 \%$ before 2050 (Food and Agriculture Organization of the United Nations, 2009). Therefore, increases in sustainable food production and management must be guaranteed, including the prevention of losses and waste throughout the food chain (Brancoli et al., 2017). Food waste issues exist at a global scale, but their specific causes vary by country, province, and even city, depending on the geographical characteristics of the territory, the type of production, infrastructure, and the profiles of consumers, among other factors (Parfitt et al., 2010). The Global Agenda Council on Logistics and Supply Chains noted fruit and vegetable losses due to improper handling and lack of proper cold transportation, such as cold logistic facilities or inadequate infrastructure (Raut et al., 2019).

In industrialized countries, a higher proportion of waste occurs at the final stages of the food supply chain such as restaurants, food industry, catering and homes than production stages, which is attributed to more exigent norms and high quality standards; however, the losses recorded at the agricultural stage are not negligible (due to aesthetic standards, product quality regulations, production surpluses, or economic factors) (Barilla Center for Food and Nutrition, 2012), while the food distribution stage (represented by companies and grocery retail stores) wastes approximately $25 \%$ of food (European Commission, 2014). FWL is 


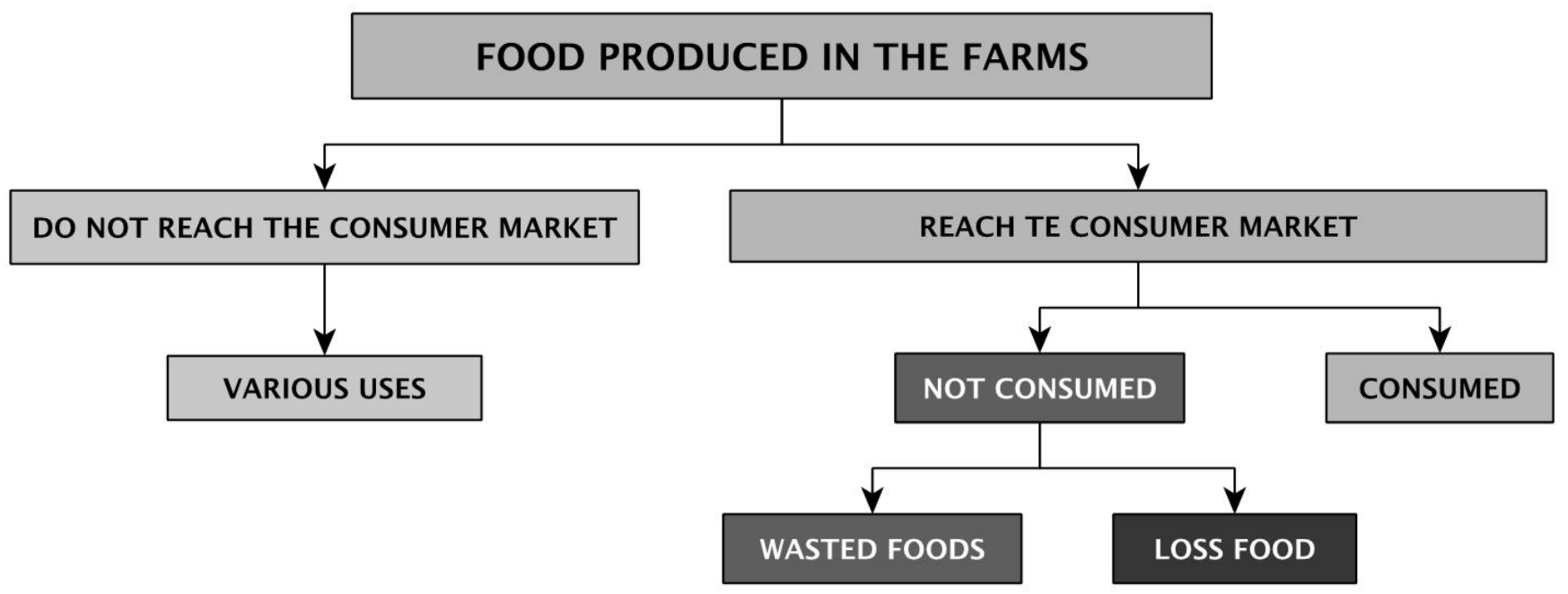

Figure 1. Schematic of food loss and waste modified from Bilska et al. (2016).

caused by inefficiencies in the food supply chain, such as poor infrastructure and logistics; lack of technology; insufficient skills, knowledge, and management capacity of supply chain actors; and lack of access to markets quickly after harvest (Food and Agriculture Organization of the United Nations, 2014). Food loss subsequently contributes to high food prices and reduces the quantity of food that is available for human consumption (Food and Agriculture Organization of the United Nations, 2011b). Optimizing the efficiency of the entire food supply chain (FSC) will be important to minimizing waste, including the identification of critical points due improper handling and lack of proper cold transportation such as cold-logistics facilities/providers or inadequate infrastructure (Raut et al., 2019).

Fruits are very diverse in their morphological, compositional, and physiological characteristics, and consequently, they are classified into groups requiring different treatments to maintain their quality and extend their postharvest shelf life (Kader, 2002). Environmental factors such as temperature, light, and air and to a lesser extent vapor pressure deficit and carbon dioxide enrichment affect the organoleptic and functional quality of vegetables ( $\mathrm{Li}$ et al., 2018). Poor handling of fresh fruits and vegetables contaminate them with harmful bacteria, viruses or parasites that deteriorate the food. The objective of this study was to identify the causes that influence the waste of foods in the fruit and vegetable sections of supermarkets.

\section{Methodology}

The study was carried out between June and July 2019 in 20 supermarkets in Mexico. Employees of two shifts were selected (morning and afternoon), and at random, they voluntarily participated in the survey. We opted to survey the employees because they are the ones who work directly with the product.

The survey was conducted by providing 15 questions on paper to the employees, and observations were made about the products and the type of exposure to the public, including their management. Some of the questions were personal in terms of level of education and experience in food handling.

\subsection{Data analysis}

The data were analysed with an inductive approach and had characteristics of grounded theory where qualitative data are systematically categorized, and a model or formal theory can be formed about the responses. A descriptive analysis was performed on the information obtained through the survey by obtaining frequencies and percentages. The commercial software Statgraphics 5.1 (Software Publishing Corporation, Bitstream) was used for the statistical analysis of the correlation between the seniority and age of the employees.

\section{Results and discussion}

\subsection{Characteristics of the study location}

In Mexico, there are two types of retailers of food products known as the modern and traditional trading systems. The modern system includes 1) convenience stores and self-service stores (supermarkets): national or international. Modern commerce offers services in medium- and high-income populations, while the traditional system preferentially caters to low-income populations.

\subsection{Characteristics of the employees surveyed}

Ninety-five percent of the surveyed staff of the fruit and vegetable sections of the different stores were male. The age varied between 21 and 52 years, with an average value of 33 years. The academic level of the staff included secondary (16.7\%), high school (70\%) and professional school (13.3\%). Among the employees surveyed, no significant correlation was found $(\mathrm{p}<0.05)$ between age and seniority in the company. The experience in the position varied between one month and ten years, but $90 \%$ of the respondents had at least one year working in the section. The importance of age was a function of experience and length of employment. 


\subsection{Training in food handling for employees}

Studies have shown that training increases knowledge of food handlers and is one of the most effective strategies for preventing food waste. A study found that the supermarkets that provide more training to staff are international chains and hypermarket national chains. The training that employees receive is given by supervisors, and the topics they include are storage, packing, and arrangement on the shelves. In international chains, employees receive seven training courses per year, while employees of national supermarkets receive only two trainings per year. Food handling must be regulated and must be mandatory to avoid food waste.

\subsection{Most-sold fruit}

The most-sold fruits in the studied supermarkets, according to the perception of those responsible for the area of fruits and vegetables, were banana, apple, melon, papaya and pineapple (Table 1) with different varieties and origins. This perception compared with existing data from the literature review and the production statistics presented in the Agro-Food Atlas 2017 (Mexico, 2017a), show they are fruits with high national consumption rates (Table 2). The survey also identified high consumption of watermelon, pear and grape (Table 1), products of acceptance in the national market but at relatively low consumption rates (Table 2) compared with those of other fruits not mentioned that are consumed widely in Mexico, such as orange (37.5 kg per capita), mango (12.2 kg per capita) and lemon (14.3 kg per capita).

\subsection{Discarded fruits}

As shown in Table 3, 20 fruits were mentioned by the different employees surveyed that were discarded for different reasons, of which 14 were marked as discarded frequently and four were wasted regularly in the 5 commercial chains: strawberry, kiwifruit, papaya, and grape, followed by banana, which was mentioned at only some of the stores. This fruit, together with grape and kiwifruit, was recorded as the first fruit wasted due to its high cost.

Table 1. Fruits considered by employees to be sold the most in supermarkets.

\begin{tabular}{cc}
\hline Fruit & $\%$ \\
\hline Banana & $30.81^{* *}$ \\
Apple & $20.35^{\star *}$ \\
Melon & $16.28^{\star *}$ \\
Papaya & $9.88^{*}$ \\
Pineapple & 9.88 \\
Watermelon & $5.81^{\star}$ \\
Pear & 5.81 \\
Grape & 1.16
\end{tabular}

${ }^{* *}$ Fruit mentioned in the five commercial chains; ${ }^{*}$ Fruit mentioned in at least 4 of the five commercial chains.
Kiwifruit was the second fruit considered among the most discarded by customers, mainly associated with its cost, although some employers considered it to be a delicate fruit that is affected by consumers (Table 3 ). To assess the firmness of the fruit, the customer touches it; if it is too soft, then it is a

Table 2. Agricultural production data of some fruits marketed in Mexico.

\begin{tabular}{lccc}
\hline Fruit & $\begin{array}{c}\text { Consumption } \\
\text { per capita }^{*}(\mathrm{~kg})\end{array}$ & $\begin{array}{c}\text { National } \\
\text { production }^{*} \\
\text { (Ton) }\end{array}$ & $\begin{array}{c}\text { World } \\
\text { production* } \\
\text { (Place) }\end{array}$ \\
\hline Banana & $15.7 \mathrm{~kg}$ & 2150520 & 11 \\
Apple & $7.6 \mathrm{~kg}$ & 716865 & 20 \\
Melon & $3.8 \mathrm{~kg}$ & 526990 & 13 \\
Papaya & $6.4 \mathrm{~kg}$ & 836370 & 5 \\
Pineapple & $6.5 \mathrm{~kg}$ & 817463 & 9 \\
Watermelon & $3.7 \mathrm{~kg}$ & 946458 & 12 \\
Pear & 0.8 & 24444 & 38 \\
Grape & 1.4 & 246858 & 29 \\
Strawberry & 1.9 & 458972 & 3 \\
Guava & 2.4 & 302718 & 5 \\
Peach & 1.6 & 173464 & 17 \\
\hline
\end{tabular}

${ }^{*}$ Data obtained from the agro-food Atlas 2017 (Mexico, 2017a).

Table 3. Fruits considered to be discarded the most and the main causes (rate of mentions by employees).

\begin{tabular}{|c|c|c|c|c|}
\hline Fruit & $\begin{array}{c}\text { Most } \\
\text { wasted \% }\end{array}$ & $\begin{array}{l}\text { Little sale } \\
\text { for cost } \%\end{array}$ & $\begin{array}{l}\text { Delicate } \\
\text { fruit } \%\end{array}$ & $\begin{array}{c}\text { Bruised by } \\
\text { clients \% }\end{array}$ \\
\hline Strawberry & $25.00^{\star *}$ & $33.66^{* *}$ & $30.65^{* *}$ & 10.71 \\
\hline Kiwifruit & $17.24^{\star \star}$ & $18.81^{* *}$ & 12.9 & 6.25 \\
\hline Papaya & $14.66^{\star *}$ & & 17.74 & $27.68^{* *}$ \\
\hline Grape & $12.93^{\star *}$ & $17.82^{*}$ & $9.68^{*}$ & $11.61^{*}$ \\
\hline Banana & 10.34 & & & 14.29 \\
\hline Melon & 4.31 & & 3.23 & $12.5^{*}$ \\
\hline Guava & 3.45 & 1.98 & & \\
\hline Peach & 2.59 & 2.97 & 6.45 & 1.79 \\
\hline Plum & 2.59 & 3.96 & 1.61 & 0.89 \\
\hline Apple & 1.72 & & & $4.46^{\star}$ \\
\hline Watermelon & 1.72 & & 1.61 & $5.36^{*}$ \\
\hline Raspberry & 1.72 & & 1.61 & \\
\hline Soursop & 0.86 & 1.98 & 3.23 & \\
\hline Passion fruit & 0.86 & 0.99 & 3.23 & \\
\hline Pear & & $6.93^{*}$ & 1.61 & \\
\hline Eggplant & & 2.97 & & \\
\hline Fig & & 1.98 & & \\
\hline Organic fruits & & 1.98 & 1.61 & \\
\hline Avocado & & 1.98 & 4.84 & \\
\hline Pitahaya & & 1.98 & & \\
\hline
\end{tabular}

${ }^{*}$ Fruit mentioned in the five commercial chains; ${ }^{*}$ Fruit mentioned in at least 4 of the five commercial chains. 
sign that the fruit has already overmatured, and the customer does not choose it.

Papaya (Table 3) is the third fruit most wasted at $14.66 \%$, and the employees perceived the cause of its waste to be bruising. In this study, papaya was the third most discarded fruit, although in contrast to strawberry and kiwifruit, its waste was not considered to be associated with the cost.

Of the grapes consumed in Mexico, 63\% are for sale for fresh consumption, and they deteriorate easily due to pathogen infection that is facilitated by their high moisture content. Table grapes were identified in the five commercial chains as a fruit with a high discarded rate, and in four of the stores, this rate was associated with their high cost and consumer manipulation (Table 3).

The fifth most popular fruit in supermarkets is bananas, and the perception of the surveyed employees is that it is damaged by the client (Table 3). Bananas are the most consumed tropical fruits and one of the most important fruits economically in the world market.

The waste of fruits and vegetables in supermarkets can be influenced by factors such as temperature, humidity, packaging, storage, and display, as well as manipulation by employees and customers due to a lack of knowledge. Some employees mentioned low sales of guava, peach, and plum due to their high cost, which would contribute to their waste, whereas melon and watermelon are two fruits that some considered delicate and bruised by customers. Apples were rarely mentioned as a product discarded, although they are often damaged by client handling of the clients (Table 3), whereas in the United States and Sweden, apples are considered one of the most wasted fruits in supermarkets (Mattsson et al., 2018).

\subsection{Wasted vegetables}

The vegetables with the highest sale volumes in the supermarkets were tomato, green hot peppers, onion and potato (Table 4), which have high levels of annual consumption per capita (Table 5). Tomato, green hot peppers, and onion are common ingredients in typical Mexican dishes, and they are used in sauces and in preparing dishes. Two green hot peppers, fresh cultivars in Mexico, are jalapeño and serrano. Mexico is the country that most consumed the green hot peppers worldwide (Neetoo \& Chen, 2012). While these products are ingredients in dishes, potato is considered the main component of some dishes because of its carbohydrate content.

The questions in the survey given to the employees were related to the perception of the most discarded vegetables, and the results noted 15 vegetables with frequent losses, considering ten as delicate products (Table 6). Tomato is an abundantly produced fruit in Mexico, and the annual national consumption of the different tomato varieties has been estimated at $30.64 \mathrm{~kg}$ per capita (Table 5) (Mexico, 2017b). Tomato was recorded as the vegetable with the highest rate of waste in all the commercial chains and the only one generally considered to require delicate handling. Stored tomatoes can present different problems caused by inadequate environmental conditions (too cold and minimal humidity) or diseases caused by different fungi and bacteria, and the right conditions vary according to the variety.
Table 4. Vegetable considered as the most sold in supermarkets (rate of mentions by employees)

\begin{tabular}{cc}
\hline Vegetable & $\%$ \\
\hline Tomato & $30.64^{* *}$ \\
Chili & $21.97^{\star *}$ \\
Onion & $20.81^{\star *}$ \\
Potato & $18.50^{\star *}$ \\
Lettuce & $6.36^{*}$ \\
Carrot & 1.16 \\
Cabbage & 0.58 \\
\hline
\end{tabular}

${ }^{*}$ Vegetable mentioned in the five commercial chains; ${ }^{*}$ Vegetable mentioned in at least 4 of the five commercial chains.

Table 5. Agricultural production data of some vegetables marketed in Mexico.

\begin{tabular}{lccc}
\hline Vegetable & $\begin{array}{c}\text { Consumption } \\
\text { per capita }\end{array}$ (kg) & $\begin{array}{c}\text { National } \\
\text { production } \\
\text { (Ton) }\end{array}$ & $\begin{array}{c}\text { World } \\
\text { production } \\
\text { (Place) }\end{array}$ \\
\hline Tomato & 14.3 & 2875164 & 10 \\
Chili & 18.7 & 2732635 & 2 \\
Onion & 10.5 & 1368184 & 12 \\
Potato & 15.6 & 1678833 & 35 \\
Lettuce & 2.6 & 406678 & 9 \\
Carrot & $\mathrm{ND}$ & $\mathrm{ND}$ & $\mathrm{ND}$ \\
Cabbage & $\mathrm{ND}$ & $\mathrm{ND}$ & $\mathrm{ND}$ \\
\hline
\end{tabular}

${ }^{*}$ Data obtained from the agro-food Atlas 2017 (Mexico, 2017a). ND: Not Detectable.

Table 6. Vegetables considered the most waste producing and the causes of waste (rate of mentions by employees).

\begin{tabular}{ccc}
\hline Vegetable & Most wasted \% & $\begin{array}{c}\text { Delicate vegetable } \\
\%\end{array}$ \\
\hline Tomato & $43.36^{* *}$ & $78.33^{* *}$ \\
Potato & $13.27^{*}$ & 1.67 \\
Onion & 8.85 & \\
Lettuce & 7.96 & 5.00 \\
Chili & $6.19^{*}$ & 3.33 \\
Cilantro & 5.31 & 3.33 \\
Chard & 4.42 & 1.67 \\
Carrot & 3.54 & 1.67 \\
Spinach & 1.77 & 1.67 \\
Celery & 1.77 & \\
Parsley & 0.88 & 1.67 \\
Asparagus & 0.88 & \\
Broccoli & 0.88 & 1.67 \\
Lemon & 0.88 &
\end{tabular}

${ }^{*}$ Vegetable mentioned in the five commercial chains; ${ }^{*}$ Vegetable mentioned in at least 4 of the five commercial chains. 
Food waste at the supermarket level is associated with negligent management of food, and this can be due to poor coordination between the volume of food received and that which can be marketed, food availability policies regarding displays to attract a higher level of customer, exotic foods offered to show a greater variety, inadequate refrigerated storage conditions, lack of personnel training the section, improper distribution of exhibited food, or mismanagement of the fruit by the customer. Even within the same store, the volume of FW varies between departments, so factors external to food, such as organizational aspects, staff behaviour, and various specific aspects, must have a significant impact (Lebersorger \& Schneider, 2014). These factors should be studied in detail to develop strategies to prevent losses and waste (Cicatiello et al., 2017).

\section{Management strategies to avoid loss and waste}

Figure 2 shows different strategies that can be developed to reduce FW in supermarket chains; the strategies identified at the retail companies studied are shown in green. The most common strategy will always be prevention through adequate management because it allows a reduction in operating costs and thus an improvement in the profits of the company. The survey asked if there was a record of the number of fruits and vegetables discarded, and the employees answered yes; however, they did not show evidence of a loss control process. The five commercial chains sell products such as natural fruit juices or cut fruits that are ready for consumption, and ripe fruits or fruits with deficient aesthetic quality are used. They also have a special day for selling fruits and vegetables where they offer discounts, and they use this as a marketing strategy.

Within the strategies identified to avoid food waste in the different supermarket chains, it was found that when some excess fruits and vegetables were not sold but were in an optimal ripening state, they were donated to a national institution called a food bank. In total, 15 companies (78.94\%) donated some percentage of food. In Mexico, the food bank (BAMX) is a civil

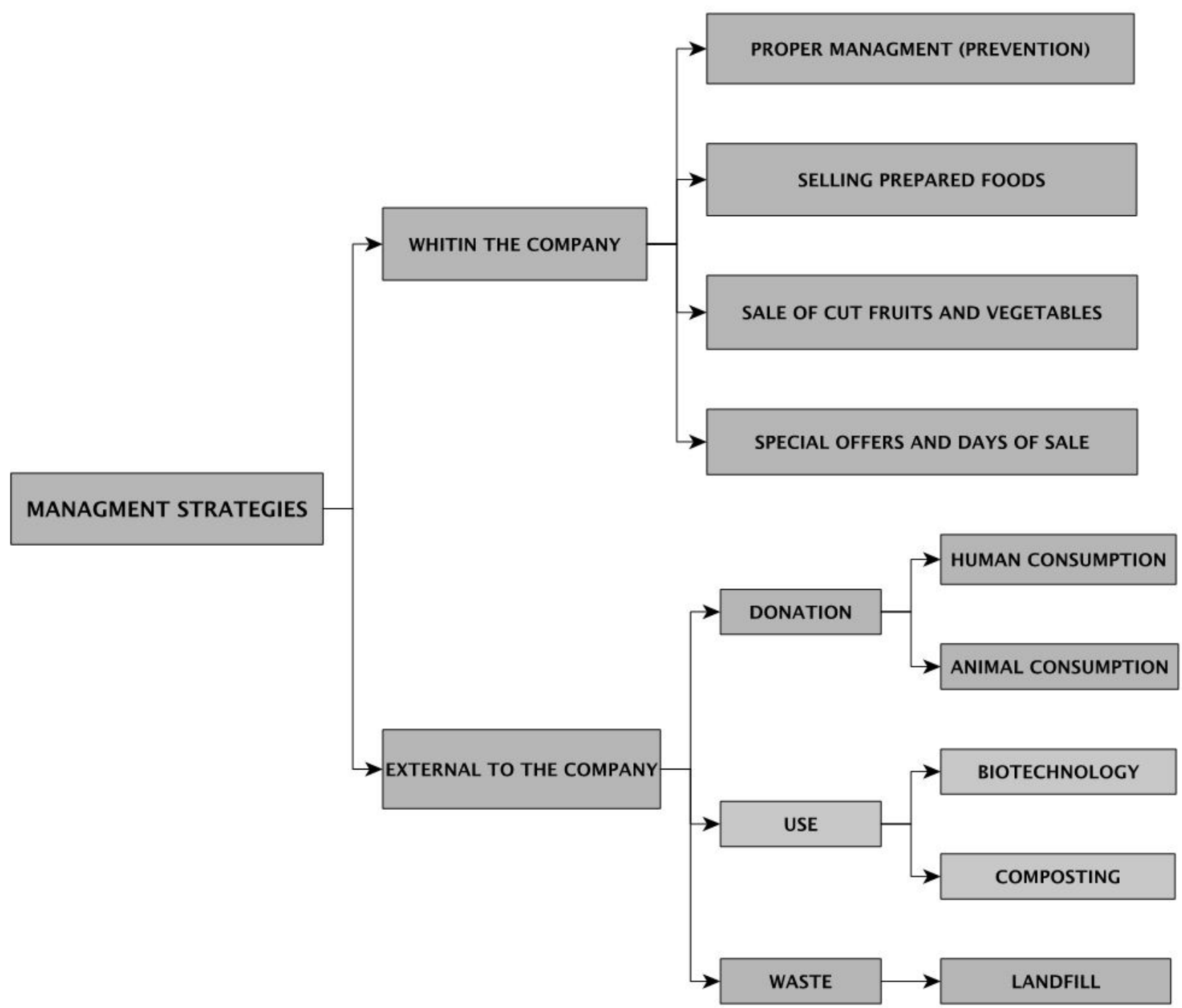

Figure 2. Management strategies used by the companies in this study to avoid waste, i.e., food and waste not used in the supermarket (Porat et al., 2018). 
organization and the only network of food banks in country, and it is the second largest food bank network in the world. The donation of safe and nutritious food represents advantages for companies, such as increasing storage space and cost savings in terms of time to dispose of the food. A donation also allows a company to advertise its actions (Lebersorger \& Schneider, 2014). Tax incentives and increased awareness that it is inappropriate to waste food from social, economic, and environmental perspectives occurred later (Mourad, 2016).

\section{Conclusions}

Reducing food waste is a prominent goal that has been set by the United Nations to achieve a more sustainable world by 2030. Carrying out actions aimed at preventing FW is a global need that results in benefits such as economic gains, mitigation of effects on the environment, and assistance with food security. Wasted fruits and vegetables are a problem with a multifactorial origin that involves issues ranging from harvest processes, transportation methods and storage conditions to administrative aspects, such as organizing and training staff that manage these perishable products throughout the marketing chain. The selection of fruits and vegetables by a consumer in retail stores is carried out subjectively by taking into account sensory aspects such as colour, taste, and texture; the loss of these attributes will influence acceptance of the products. In the handling of fruits and vegetables, professional preparation is required since each fruit or vegetable requires specific environmental conditions, such as a specific temperature, relative humidity, pressure and composition of gas, to maintain the quality and useful life of the products. It is necessary to implement policies and programmes to reduce food waste.

\section{Acknowledgements}

Technical and academic support from RED 12.3 PDA is gratefully acknowledged.

\section{References}

Barco, H., Oribe-Garcia, I., Vargas-Viedma, M. V., Borges, C. E., Martín, C., \& Alonso-Vicario, A. (2019). New methodology for facilitating food wastage quantification. Identifying gaps and data inconsistencies. Journal of Environmental Management, 234, 512-524. http://dx.doi. org/10.1016/j.jenvman.2018.11.037. PMid:30654243.

Barilla Center for Food and Nutrition - BCFN. (2012). Food waste: causes, impacts and proposal. Retrieved from https://www.barillacfn. $\mathrm{com} / \mathrm{m} /$ publications/food-waste-causes-impact-proposals.pdf

Bilska, B., Wrzosek, M., Kołożyn-Krajewska, D., \& Krajewski, K. (2016). Risk of food losses and potential of food recovery for social purposes. Waste Management, 52, 269-277. http://dx.doi.org/10.1016/j. wasman.2016.03.035. PMid:27026493.

Brancoli, P., Rousta, K., \& Bolton, K. (2017). Life cycle assessment of supermarket food waste. Resources, Conservation and Recycling, 118, 39-46. http://dx.doi.org/10.1016/j.resconrec.2016.11.024.

Broekmeulen, R., \& Van Donselaar, K. H. (2019). Quantifying the potential to improve on food waste, freshness and sales for perishables in supermarkets. International Journal of Production Economics, 209, 265-273. http://dx.doi.org/10.1016/j.ijpe.2017.10.003.
Cicatiello, C., Franco, S., Pancino, B., Blasi, E., \& Falasconi, L. (2017). The dark side of retail food waste: evidences from in-store data. Resources, Conservation and Recycling, 125, 273-281. http://dx.doi. org/10.1016/j.resconrec.2017.06.010.

Corrado, S., Caldeira, C., Eriksson, M., Hanssen, O. J., Hauser, H.-E., Van Holsteijn, F., Liu, G., Östergren, K., Parry, A., Secondi, L., Stenmarck, Å., \& Sala, S. (2019). Food waste accounting methodologies: challenges, opportunities, and further advancements. Global Food Security, 20, 93-100. http://dx.doi.org/10.1016/j.gfs.2019.01.002. PMid:31008044.

European Commission. (2014). Fusions definitional framework for food waste: full report. Brussels. Retrieved from https://www.eu-fusions. org/phocadownload/Publications/FUSIONS\%20Definitional\%20 Framework\%20for\%20Food\%20Waste\%202014.pdf

Food and Agriculture Organization of the United Nations - FAO. (2009). Global agriculture towards 2050. Rome. Retrieved from http://www.fao.org/fileadmin/templates/wsfs/docs/Issues_papers/ HLEF2050_Global_Agriculture.pdf

Food and Agriculture Organization of the United Nations - FAO. (2011a). Food loss and food waste. Rome. Retrieved from http:// www.fao.org/food-loss-and-food-waste/en/

Food and Agriculture Organization of the United Nations - FAO. (2011b). Food wastage footprint and climate change. Rome. Retrieved from http://www.fao.org/3/a-bb144e.pdf

Food and Agriculture Organization of the United Nations - FAO. (2014). Pérdidas y desperdicios de alimentos en América Latina y el Caribe. Rome. Retrieved from http://www.fao.org/americas/noticias/ver/es/c/239393/

Gustavsson, J., Cederberg, C., Sonesson, U., van Otterdijk, R., \& Meybeck, A. (2011). Global food losses and food waste: extent, causes and prevention. Rome: FAO. Retrieved from http://www.fao.org/3/a-i2697e.pdf

Kader, A. A. (2002). Postharvest biology and technology: an overview. In A. A. Kader (Ed.), Postharvest technology of horticultural crops (3rd ed., Publication, No. 3311, pp. 39-47). Oakland, CA: Division of Agriculture and Natural Resources, University California.

Lebersorger, S., \& Schneider, F. (2014). Food loss rates at the food retail, influencing factors and reasons as a basis for waste prevention measures. Waste Management, 34(11), 1911-1919. http://dx.doi. org/10.1016/j.wasman.2014.06.013. PMid:25060676.

Li, D., Zhu, Z., \& Sun, D. (2018). Effects of freezing on cell structure of fresh cellular food materials: a review. Trends in Food Science \& Technology, 75, 47-55. http://dx.doi.org/10.1016/j.tifs.2018.02.019.

Mattsson, L., Williams, H., \& Berghel, J. (2018). Waste of fresh fruit and vegetables at retailers in Sweden: measuring and calculation of mass, economic cost and climate impact. Resources, Conservation and Recycling, 130, 118-126. http://dx.doi.org/10.1016/j.resconrec.2017.10.037.

Mexico, Secretaria de Agricultura y Desarrollo Rural - SAGARPA. (2017a). Atlas agroalimentario 2017. Mexico, D.F. Retrieved from http://online.pubhtml5.com/clsi/ibhs/

Mexico, Secretaria de Agricultura y Desarrollo Rural - SAGARPA. (2017b). Planeación agicola nacional 2017-2030: uva mexicana. Mexico, D.F. Retrieved from https://www.gob.mx/cms/uploads/ attachment/file/257085/Potencial-Uva.pdf

Mourad, M. (2016). Recycling, recovering and preventing "food waste": competing solutions for food systems sustainability in the United States and France. Journal of Cleaner Production, 126, 461-477. http://dx.doi.org/10.1016/j.jclepro.2016.03.084.

Neetoo, H., \& Chen, H. (2012). High pressure inactivation of Salmonella on Jalapeño and Serrano peppers destined for direct consumption or as ingredients in Mexican salsa and guacamole. International Journal of Food Microbiology, 156(3), 197-203. http://dx.doi.org/10.1016/j. ijfoodmicro.2012.03.019. PMid:22534353. 
Parfitt, J., Barthel, M., \& Macnaughton, S. (2010). Food waste within food supply chains: quantification and potential for change to 2050. Philosophical transactions of the Royal Society of London. Series B, 365(1554), 3065-3081. http://dx.doi.org/10.1098/rstb.2010.0126. PMid:20713403.

Porat, R., Lichter, A., Terry, L. A., Harker, R., \& Buzby, J. (2018). Postharvest losses of fruit and vegetables during retail and in consumers' homes: quantifications, causes, and means of prevention. Postharvest Biology and Technology, 139, 135-149. http://dx.doi. org/10.1016/j.postharvbio.2017.11.019.
Raut, R. D., Gardas, B. B., Narwane, V. S., \& Narkhede, B. E. (2019). improvement in the food losses in fruits and vegetable supply chain: a perspective of cold third-party logistics approach. Operations Research Perspectives, 6, 100117. http://dx.doi.org/10.1016/j. orp.2019.100117.

Wunderlich, S. M., \& Martinez, N. M. (2018). Conserving natural resources through food loss reduction: production and consumption stages of the food supply chain. International Soil and Water Conservation Research, 6(4), 331-339. http://dx.doi.org/10.1016/j. iswcr.2018.06.002. 